\title{
JóZEF KOREDCZUK
}

Uniwersytet Wrocławski

\section{ZNACZENIE KODEKSU KARNEGO Z 1932 R. DLA ROZWOJU NAUKI I PRAWA KARNEGO W POLSCE W XX WIEKU}

Już w trzy i pół roku po uchwaleniu kodeksu karnego z 1932 r., w grudniu 1935 r. w ramach serii odczytów na posiedzeniach Towarzystw Prawniczych pod tytułem Kodeks karny r. 1936 a nowa konstytucja polska Emil Stanisław Rappaport mówił, iż „należy uznać jako zjawisko wysoce pożądane, że rozpoczęło się już badanie Kodeksu Karnego Polskiego z r. 1932 pod kątem widzenia jego wskazań podstawowych i oryginalnie polskiej a wielce dla naszego stulecia i dla obecnej chwili dziejowej charakterystycznej myśli przewodniej"'. E.S. Rappaport, a priori z dużą jednak dozą prawdopodobieństwa przewidywał, że kodeks karny z 1932 r. odegra przełomową rolę w dziejach prawa polskiego. A nie było to tak oczywiste.

Nikt w momencie tworzenia kodeksu nie przypuszczał, że będzie on tak dobry. Chociaż już w trakcie prac nad projektem kodeksu można by wskazać podstawy ku temu, iż tak będzie. Ponieważ w trakcie prac nad projektem często odwoływano się do projektów szwajcarskiego kodeksu karnego, którego głównym autorem był Karl Stooss² ${ }^{2}$ Wacław

${ }^{1}$ E.S. RAPPAPORT, Kodeks karny r. 1936 a nowa konstytucja polska, «Palestra» 13.4/1936, s. 251.

${ }^{2}$ M. TARnAwSKI, Ksztaltowanie sie ustawodawstwa karnego polskiego w latach 1918-1994. Prawo karne materialne, [w:] Historia prawa. Historia kultury. 'Liber 
Makowski, drugi spośród najważniejszych współtwórców kodeksu, w trakcie prac nad nim, z kolei często powoływał się na norweski kodeks karny z 1902 r., którego autorem był B. Goetz, jedną lepszych ówczesnych europejskich kodyfikacji karnych, ale trochę już przestarzałą i stosunkowo mało znaną ${ }^{3}$. Projekt ten był także konsultowany z zagranicznymi uczonymi, jak chociażby z Jean'em André Rouxem (sekretarzem generalnym Międzynarodowego Stowarzyszenia Prawa Karnego, Association Internationale de Droit Pénal), któremu bardziej jednak przypadła do gustu wersja projektu przygotowana przez W. Makowskiego, niż Juliusza Makarewicza ${ }^{4}$.

Bardzo szybko po uchwaleniu także kodeks stał się znany za granicą. Sam J. Makarewicz przetłumaczył tekst polskiego kodeksu karnego na język niemiecki, które to thumaczenie nakładem Verlag des Hilfsarbeitenbüros der Kodifikationskomission ukazało się w 1932 r. Już w styczniu 1933 r. na posiedzeniu Institut Osteuropa we Wrocławiu podstawowe jego założenia przedstawił Stefan Glaser. Krótkąjego charakterystykę w 1933 r. w Dreźnie opublikował Grzegorz Wirszubski (Das polnische Strafgesetzbuch vom 11. VII. 1932 und kriminalpolitischen Forderungen der Gegenwart). Zaś czasopismo «Zeitschrift für Ostrechrt» w 1933 r. wydało cykl monografii dotyczących polskiej kodyfikacji karnej, między innymi S. Glasera das neue polnische Strafgesetzbuch Und die deutsche Strafrechtsform, J. Makarewicza Das Strafgesetzbuch für die Republik Polen oraz Wenzla Grafa Gleispacha

Memorialis Vitoldo Maisel dedicatus', red.: E. Borkowska-Bagieńska, H. Olszewski, Poznań 1994, s. 399.

3 E. DARmorost-SiERocińSKA, Kodyfikacja prawa karnego w 1932 roku a ksztattowanie się polskiej myśli prawniczej, «CPH»62.1/2010, s. 362-365. Por. także TeJżE, Odpowiedzialność karna $w$ dawnych kodyfikacjach norweskiej i polskiej. Próba ujęcia porównawczego, «CPH» 61.1/2009, s. 273-290; W. MAKowsKI, Nowy Kodeks Karny Norweski, przekład postanowień szczegółowych i uwagi, [w:] Materiały do Kodyfikacji Prawa karnego opracowane przez Sekcję karna Towarzystwa Prawniczego $w$ Warszawie, I, Warszawa 1916. Z oceną W. Makowskiego norweskiego kodeksu karnego w wielu punktach nie zgadzał się jednak J. Makarewicz.

${ }^{4}$ J.A. Roux, O części ogólnej projektu Kodeksu Karnego Polskiego, «Gazeta Sądowa Warszawska" 53.3/1925, s. 35-36. 
Das polnische Strafgesetzbuch . Później natomiast w 1939 r. na forum «Blätter für Gefängniskunde», krótkie przyczynki dotyczące poszczególnych instytucji w nim zawartych przedstawili Ludwik Dworzak (uczeń J. Makarewicza) i Tadeusz Mitraszewski'.

Jako bardzo nowoczesny został on również oceniony przez wybitnych prawników zagranicznych (Pierre'a Garrauda, Roberta von Hippela, K. Stoossa, Edmunda Mezgera) po jego uchwaleniu. Zwrócili oni uwagę na takie cechy kodeksu jak: jasność, syntetyczność ujęć, spójność. Uznawali oni go za „technicznie doskonały zlepek różnolitych postulatów kodyfikacyjnych, jakimś „cudem koncesyj” (miracolo dei concessioni) kryminologicznej prawicy i lewicy"7. „Zlepek” ten rzeczywiście był właściwym, kodeksowi bowiem przyjdzie mu obowiązywać zarówno pod rządami „prawicy”, jak i „lewicy”, chodzi oczywiście o polityczną „prawicę” i „lewicę”.

Krytycznie natomiast ocenił polski kodeks karny w 1935 r. na łamach czołowego czasopisma niemieckiego, zajmującego się prawem karnym «Zeitschrift für die gasamte Strafrechtswissenschaft» docent Richard Busch ${ }^{8}$. Biorąc pod uwagę, że oceny tej dokonywał on w stosunku do ówczesnego niemieckiego, hitlerowskiego prawa karnego, dziś po latach tą ocenę także można uznać za pozytywną9.

Był to kodeks ,eklektyczny”, ale w pozytywnym tego słowa znaczeniu. Nie popadając bowiem w skrajności jego twórcy wykorzysta-

5 J. Koredczuk, Poglady Juliusza Makarewicza na zmiany $w$ prawie karnym niemieckim po 1933 roku, «Acta Universitatis Wratislaviensis» nr 2750. «Studia nad Faszyzmem i Zbrodniami Hitlerowskimi» 28/2005, s. 394.

${ }^{6}$ L. Dworzak, Die Grundgedanken des polnischen Strafgesetzes, «Blätter für Gefängniskunde» 69/1939, s. 419-426; T. MitrasZEwSKI, Strafmittel und Sicherungsmaßregeln auf Grund der polnischen Strafvollzugspraxis, «Blätter für Gefängniskunde» 69/1939, s. 421-428).

7 E. S. RAPPAPORT, 'Media via' kodeksu karnego polskiego, «Palestra»12.4/1935, S. 285.

${ }^{8}$ R. Busch, Kritische Bemerkungen zum polnischen Strafgesetzbuch, «Zeitschrift für die gesamte Strafrechtswissenschaft» 55.4-5/1935, s. 636-643.

9 Por. J. W. ŚLIwowski, Kodeks Karny Polski w opinji obcych, «Głos Sądownictwa» 8.7-8/1936, s. 593-595. 
li osiagnnięcia różnych koncepcji jakie pojawiły się w filozofii prawa karnego na przełomie XIX i XX w. Kodeks ten powszechnie uznano za najlepszy europejski kodeks karny, obok o pięć lat młodszego kodeksu szwajcarskiego z 1937 r. Nawet burzliwe zmiany ustrojowe w Polsce po II wojnie światowej nie spowodowały uchylenia tego kodeksu. Jego wartość - głównie części ogólnej - miała charakter ponadustrojowy. Jego podstawowe rozwiązania dogmatycznoprawne legły u podstaw kodeksu z 1969 r. ${ }^{10}$. W kodyfikacji z 1969 r. musiano uwzględnić te podstawowe założenia kodeksu karnego z 1932 r., które wytrzymały ciężką próbę czasu ${ }^{11}$. Nawet jego oponenci musieli uznać w tym zakresie jego wielkość. Możnaby pokusić się o paralelę do sytuacji oskarżonego $\mathrm{w}$ inkwizycyjnym procesie karnym, że kodeks z 1932 r. - w latach 1944-1969 - także został poddany torturom, które zwycięsko wytrzymał. Do kodeksu karnego z 1932 r., jako wyrazu znakomitych tradycji prawodawstwa polskiego, nawiązywał kodeks karny z 1969 r. również w warstwie techniczno-legislacyjnej ${ }^{12}$.

Pomimo, że z krytyka, często słuszną, spotkały się niektóre jego rozwiązania części ogólnej (np. dotyczące systemu kar przewidzianego w kodeksie) oraz niektóre działy części szczególnej (np. przestępstwa przeciwko państwu), to także i ta krytyka okazała się twórcza. Na jej bowiem gruncie wyrosły w polskim prawie karnym nowe rozwiązania nadążające za „duchem czasu”, zmian w Polsce i postępu w nauce prawa karnego.

Część ogólna kodeksu nie tylko, że nadal formalnie po II wojnie światowej obowiązywała, to została nawet recypowana do jakże kontrowersyjnego kodeksu, jakim był kodeks karny Wojska Polskiego z 23 września 1944 r. W drodze interpretacji sądowej nadano jej oczywiście zupełnie nowy sens, nową socjalistyczną treść. Dzięki czemu kodeks karny z 1932 r. obowiązywał po wojnie przez 25 lat, stano-

10 M. TARnAWSKI, op. cit., s. 401.

11 T. Bojarski, Cz. Gofroń, Tradycja i postępowe idee w polskim kodeksie karnym z 1969 r. na przykladzie wybranych instytucji, [w:] Tradycja i postęp w prawie. Zbiór rozpraw, red. R. TOKARCZYK, Lublin 1983, s. 126.

12 A. Marek, Prawo karne. Zagadnienia teorii i praktyki, Warszawa 1997, s. 17. 
wiąc pod tym względem swoisty fenomen, biorąc pod uwagę inne kraje socjalistyczne i wpisując się w aksjologię obowiązującego prawa w Polsce ${ }^{13}$. Należy również pamiętać, że w kodeksie były także przepisy dotyczące przestępstw popełnionych przez nieletnich - oceniane jako jedne z najlepszych - które obowiązywały nie do 1970 r. (do wejścia w życie kodeksu karnego z 1969 r.), lecz do wejścia w życie ustawy z dnia 26 października 1982 r. o postępowaniu w sprawach nieletnich. Przy czym w ustawie z 1982 r. przejęto rozwiązania o charakterze profilaktycznym, których jednym ze współautorów był J. Makarewicz a które konsultował on z przedstawicielami nauki prawa austriackiego. Rozwiązania te do dziś mieszczą się w wysokim standardzie europejskim, mając doniosłe znaczenie na tle europejskiego stanu prawnego ${ }^{14}$.

Kodeks po II wojnie światowej nie przestał także wywierać wpływu na rozwój nauki prawa karnego. Dowodem na to może być fakt, że $\mathrm{w}$ trakcie dyskusji nad stanem i zadaniami nauki prawa przed I Kongresem Nauki Polskiej w 1950 r., podkreślano że w polskim piśmiennictwie prawniczym powojennym nadal przeważały metody i wpływy burżuazyjne. Wydawano nadal podręczniki, także do prawa karnego, które w swojej treści i metodzie w niczym nie odbiegały od podręczników wydanych przed wojną ${ }^{15}$. I nie ukazał się do niego żaden nowy komentarz. Jedynie komentarz Jerzego Nisensona i Mieczysława Siewierskiego (Kodeks karny i prawo o wykroczeniach. Komentarz, orzecznictwo, przepisy wprowadzajace i zwiqzkowe, wydanie 7, Łódź 1949) doczekał się czterech wznowień, którym zarzuca-

13 A. GrześKowiak, Aksjologia komunistycznego prawa karnego w Polsce Ludowej, [w:] Komunistyczne prawo karne Polski Ludowej, red. A. GrzeŚKOwIAK Lublin 2007, s. 19.

14 T. Bojarski, Tradycja i postę w nowelizacji prawa karnego - od Makarewicza do stanu obecnego. «Teki Komisji Prawnej. Polska Akademia Nauk. Oddział w Lublinie» $1 / 2008$, s. 13.

15 S. Rozmaryn, Wstępne tezy referatu ogólnego o stanie i zadaniach nauki prawa $w$ Polsce, [w:] Stan nauki prawa karnego. Konferencja teoretyków i praktyków prawa karnego. Materiały z prac przygotowawczych do I Kongresu Nauki Polskiej, Warszawa 1950, s. 30-31. 
no, że jedynie częściowo i bezkrytycznie adnotacje do poszczególnych artykułów w nim zostały uzupełnione o judykaturę powojenną ${ }^{16}$.

Podobnie w 1970 r. po wejściu w życie nowego kodeksu karnego z 1969 r., na konferencji poświęconej problemom nowego prawa karnego, prowadzący obrady Igor Andrejew otworzył je mówiąc, iż „nie bez żalu wielu $\mathrm{z}$ nas spoglądało na przepisy wprowadzające nowy [czyli z 1969 r. - J.K.] kodeks karny, według których <uchyla się kodeks karny ... z dnia 11 lipca 1932 roku>. Była i jest to troska, którą się przeżywa, gdy dostaje dymisję ktoś bardzo ważny i zasłużony, po którym wiadomo, czego się można było spodziewać, a przychodzi ktoś młody, ale nowy"17.

Inny zaś przedstawiciel władz, ówczesny minister sprawiedliwości Stanisław Walczak na tej samej konferencji zwrócił uwagę „na szczególną zbieżność w pracach nad kodyfikacją [z 1969 r. - J. K.], wyrażającą się faktem aktywnego udziału przedstawicieli nauki prawa nie tylko pamiętających prace nad kodyfikacją z okresu międzywojennego, szczególnie kodeksu z 1932 r., ale czynnie w niej uczestniczących, oraz prawników pokolenia wyrosłego już po II wojnie światowej. Znalazła ona - sądzę - wyraz w fakcie kontynuacji myśli i dorobku polskiej nauki prawa, jej postępowego nurtu oraz przyjęciu najlepszych doświadczeń"18.

Czołowi przedstawiciele polskiej nauki prawa karnego po II wojnie światowej, zarówno „starzy” - Stanisław Śliwiński, czy Władysław Wolter, jak i „młodzi” - I. Andrejew, Leszek Lernell, czy Jerzy Sawicki (ale wykształceni przed wojną na kodeksie), wychodząc w ramach wykładni kodeksu karnego z 1932 r. doszli do szeregu nowych konstrukcji, w szczególności przy zagadnieniach istoty przestępstwa, bezprawności, obrony koniecznej, stanu wyższej konieczności, czy niepoczytalności.

${ }_{16}$ Stan nauki prawa karnego w Polsce, [w:] Stan nauki prawa karnego..., s. 92.

17 I. AndReJew, Wprowadzenie, [w:] Problemy nowego prawa karnego. Materiały konferencji naukowej zorganizowanej przez Komitet Nauk Prawnych Polskiej Akademii Nauk w dniach 4-6 maja 1970 roku w Warszawie, red. I. ANDREJEW Wrocław 1973, s. 7.

18 S. Walczak, Przemówienie wstepne, [w:] Problemy nowego prawa karnego..., s. 11 . 
Kodeks karny z 1932 r. również pośrednio wpływał na rozwój polskiej nauki prawa karnego po II wojnie światowej. Nauka bowiem prawa karnego tym się różni od innych, że w prawie sądowym elementem współtwórczym jest judykatura, a podstawą tej do 1970 r. był kodeks karny z $1932 \mathrm{r}$.

Kodeks z 1932 r. - pomimo różnych ,ale”, które zawsze w dyskusji nad nim się pojawiały - w nauce polskiej po II wojnie światowej z reguły był oceniany pozytywnie, odmiennie natomiast było wśród praktyków. Od razu należy zastrzec, że owa negatywna ocena kodeksu ze strony praktyków była formułowana głównie przez ,prawników rządowych" i w oficjalnych wystąpieniach. Prywatnie bowiem większość prawników polskich dalej bardzo pozytywnie go oceniała ${ }^{19}$. Różnice te uzasadniano brakiem kontaktu nauki prawa karnego z wymiarem sprawiedliwości oraz różnicami światopoglądowymi pomiędzy przedstawicielami nauki prawa karnego a praktykami ${ }^{20}$. Zwłaszcza ten drugi czynnik wart jest zwrócenia uwagi. Pierwszy bowiem był łatwy do zniwelowania, drugi natomiast nie. Wymagał nie tylko wymiany ludzi, ale również tego jak oni myślą. A to w przypadku karnistów nie było takie proste tak długo, jak długo nawet tylko formalnie obowiązywał kodeks karny z 1932 r. Pamiętać bowiem należy, że w okresie obowiązywania kodeksu karnego z 1932 r. wykształciło się na nim kilka pokoleń, kilkadziesiąt tysięcy prawników.

Pamiętać także należy o tym, że kodeks karny z 1932 r. do 1970 r. był podstawą wykładu prawa karnego na Wydziałach Prawa, a podstawowa rola tego wykładu wyrażała się nie tylko na analizie jego przepisów, ale również przedstawieniu okoliczności jego powstania i rozwiązań teoretyczno-prawnych, które legły u jego podstaw.

Pamiętajmy również, że wśród młodszego pokolenia profesorów prawa karnego po II światowej byli także nieliczni uczniowie J. Makarewicza - Zdzisław Papierkowski (na Katolickim Uniwersytecie Lubelskim)

19 A. Lityński, Pół wieku kodyfikacji prawa w Polsce (1919-1969). Wybrane zagadnienia, Tychy 2001, s. 79.

${ }^{20}$ Przebieg dyskusji nad referatem o stanie nauki prawa karnego, [w:] Stan nauki prawa karnego..., s. 66 (głos w dyskusji Henryka Podlaskiego). 
oraz najmłodszy jego uczeń Stanisław Pławski (na Uniwersytecie Łódzkim), którzy nie jako z urzędu byli jego obrońcami ${ }^{21}$.

Wraz z upływem czasu zmieniła się również funkcja kodeksu karnego z 1932 r. O ile przed II wojną światową nie zawsze był on doceniany przez przedstawicieli nauki, co było wynikiem różnych sporów wśród nich, a z kolei Sąd Najwyższy niekiedy nawet zbyt stanowczo stał na straży granic jego przestrzegania. O tyle po II wojnie światowej odwróciły się role. Ze strony Sądu Najwyższego szły najczęstsze ataki na niego, jego praktyka odrzucała, nie chciała korzystać z tych postępowych rozwiązań kodeksu do których odwoływano się w okresie przedwojennym. Gdzie właśnie sędziowie Sądu Najwyższego niekiedy byli ostatnimi obrońcami kodeksu przed zamachami ze strony polityków, czy władz administracyjnych. Po II wojnie światowej, rolę tą w ograniczonym zakresie - możliwości bowiem nauki prawa karnego były tu mniejsze niż Sądu Najwyższego - przejęła z kolei nauka prawa.

Polskie prawo karne od 1918 r. tworzone jest przez przedstawicieli nauki i praktyki niekiedy pozostających w sporze, ale często także w owocnym współdziałaniu. Jak pokazały doświadczenia polskich kodyfikacji karnych jakość ich w znacznym stopniu zależna była od tego, czy przedstawiciele nauki mieli przy ich tworzeniu dostatecznie duże możliwości wypowiadania się i wpływania na ich kształt, czy też nie $^{22}$.

Przedstawicielom polskiej nauki prawa karnego, broniącym po II wojnie światowej, kodeksu karnego z 1932 r. zarzucano niekiedy skrajny dogmatyzm. Nie ma co się temu dziwić, metoda bowiem dogmatyczna jest jedną z podstawowych metod badawczych w nauce prawa karnego, ale dobry jakościowo dogmatyzm okazuje się dawał się pogodzić nawet z metodologią marksistowską. Oczywiście nie od razu, ale po 1956 r., kiedy to prace nad kodeksem karnym z 1969 r.

${ }^{21}$ A. Redzik, Profesor Juliusz Makarewicz - życie i dzieło, [w:] Prawo karne w pogladach profesora Juliusza Makarewicza, red. A. GRzé́KOWIAK, Lublin 2005, s. 56-57 i 61-62.

22 J. Tylman, Rola nauki w zakresie kodyfikacji prawa karnego procesowego, «Acta Universitatis Lodziensis Folia Iuridica» 64/1997, s. 135. 
weszły w fazę końcową i względy ideologiczne uległy zrównoważeniu ze względami formalno-dogmatycznymi. Pamiętać przy tym należy, że J. Makarewicz był jednym z niewielu - żeby nie powiedzieć jedynym - z polskich uczonych, którzy swoją spuścizną trwale wpisali się do światowego dorobku nauki prawa ${ }^{23}$.

Znaczenia kodeksu karnego z 1932 r. nie przekreśliło nawet to, że nauka i ustawodawstwo karne socjalistycznej Polski formowały się w wyraźnej opozycji do idei szkoły socjologicznej na gruncie której jak wiadomo powstał ten kodeks ${ }^{24}$. Dzięki temu, że był tak nowoczesny mógł służyć - pomimo licznych zmian - ochronie stosunków społecznych w Polsce nawet w nowych warunkach społeczno-gospodarczych i ustrojowych. Wprawdzie do 1956 r. trudno jest mówić o tradycjach polskiego prawa karnego, gdyż kształtowało się ono głównie pod wpływem wzorców zewnętrznych (wiadomo jakich). Tak później w latach 1956-1989 o polskim prawie karnym można powiedzieć, że było ono najbardziej liberalne wśród systemów prawnych państw realnego socjalizmu ${ }^{25}$. I była to w dużym stopniu zasługa do 1970 r. obowiązywania a po tym roku oddziaływania kodeksu z 1932 r. Pamiętajmy również, że w wyniku różnych reform prawa karnego w Polsce po II wojnie światowej, jak chociażby wprowadzenia w 1946 r. sławnego tzw. małego kodeksu karnego ${ }^{26}$, System prawa karnego materialnego z 1932 r. formalnie nie uległ zmianie, na podstawie bowiem małego kodeksu karnego niektóre przepisy kodeksu karnego uległy jedynie zawieszeniu, a nie uchyleniu. Podobnie było z wieloma innymi przepisami wchodzącymi w skład ówczesnego polskiego sys-

${ }^{23}$ P. Kardas, Juliusza Makarewicza filozofia prawa karnego a podstawowe zasady odpowiedzialności karnej we wspótczesnym prawie karnym, [w:] Dziedzictwo prawne XX wieku. Księga pamiatkowa z okazji 150-lecia Towarzystwa Biblioteki Stuchaczów Prawa Uniwersytetu Jagiellońskiego, Kraków 2001, s. 511.

${ }^{24}$ A. WASEK, Refleksja nad zagadnieniami tradycji i postępu $w$ polskim prawie karnym, [w:] Tradycja i postęp w prawie..., s. 102.

25 J. SKupiński, Polskie prawo karne: tradycja a współczesność, «Studia Prawnicze» 55.1/2002, s. 44.

${ }^{26}$ Por. dekret z dnia 13 czerwca 1946 r. o przestępstwach szczególnie niebezpiecznych w okresie odbudowy Państwa (Dz.U. Nr 30, poz. 192). 
temu prawa karnego materialnego. Zaczęto natomiast tworzyć równoległy do kodeksu, odrębny „socjalistyczny” system prawny ${ }^{27}$.

U podstaw przystapienia do tworzenia nowego "socjalistycznego" systemu prawnego i podjęcia prac nad nowym kodeksem legły wyłącznie czynniki natury politycznej. Powołana bowiem w 1952 r. przy Ministerstwie Sprawiedliwości Komisja Konsultacyjno-Naukowa miała za zadanie „dostosowanie” przepisów prawa karnego do zasad ustrojowych Polski. Natomiast sprawa kodyfikacji wśród praktyków nie budziła zainteresowania, oceniali oni bowiem kodeks z 1932 r. bardzo dobrze i obawiali się, że owo „dostosowywanie” może mu tylko zaszkodzić, a nie pomóc ${ }^{28}$.

Pomimo w pierwszych latach po II wojnie światowej procesu dekodyfikacji prawa karnego materialnego, wywodzącego się z II Rzeczypospolitej, a w późniejszym czasie podjęciem prac nad nowym „ludowym" kodeksem karnym²9, znaczenie kodeksu karnego z 1932 r. nigdy całkowicie nie zgasło. Kodeks karny z 1932 r. do dziś wywiera wpływ na rozwój nauki i prawa karnego w Polsce. Jest to możliwe dzięki temu, iż w prawie karnym - nawet pomimo rozwoju nowych kierunków w nauce i postulatów przebudowy prawa karnego - niemożliwe jest generalnie zerwanie z pewnymi utrwalonymi kanonami odpowiedzialności i karania (np. nullum crimen sine lege, nullum crimen sine culpa, nulla poena sine lege anteriori) ${ }^{30}$. Tymi kanonami, które w polskim prawie karnym po raz pierwszy znalazły się właśnie dzięki kodeksowi karnemu z 1932 r. i które miały i nadal zachowały niekwestionowaną wartość, które w okresie międzywojennym uzna-

27 A. Machnikowska, Wymiar sprawiedliwości w Polsce w latach 1944-1950, Gdańsk 2008, s. 336-337.

28 A. LitYŃSKI, Nowe ustawodawstwo w nowym ustroju. O prawie karnym i cywilnym w pierwszym dwudziestoleciu Polski Ludowej, «Miscellanea Historico-Iuridica» 4/2006, s. 131-132.

29 A. StawarsKa-Rippel, Uwagi o obowiqzywaniu kodeksu karnego z 1932 roku $w$ Polsce Ludowej na tle stosowania artykułu 84 k.k., «Z Dziejów Prawa»7/2005, s. 152; TEJże, Prawo sqdowe Polski Ludowej 1944-1950 a prawo Drugiej Rzeczypospolitej, Katowice 2006, s. 60.

30 T. Bojarski, Cz. Gofroń, op. cit., s. 126-127. 
wano powszechnie za niepodważalne „dogmaty” polskiego prawa karnego i o których w 1936 r. J. Makarewicz powiedział, iż „wychowywały się na nich całe generacje prawników w XIX i XX w." ${ }^{31}$. Do dziś sformułowane w kodeksie karnym z 1932 r. przez J. Makarewicza zasady subiektywizmu i indywidualizacji odpowiedzialności karnej oraz humanitaryzmu w operowaniu środkami karnymi zachowują w pełni aktualność, stanowiąc podstawę ustawowych przesłanek odpowiedzialności we wszystkich nowożytnych kodeksach karnych oraz jądro współczesnych koncepcji teoretycznych ${ }^{32}$. Również inne koncepcje teoretyczne sformułowane przez J. Makarewicza, stanowiące dziedzictwo XX w. przeszły do nauki prawa karnego XXI w. Chodzi tu szczególnie o jego koncepcję odpowiedzialności za podżeganie i pomocnictwo do przestępstw indywidualnych, która pomimo że była $\mathrm{i}$ jest poglądem mniejszościowym $\mathrm{w}$ doktrynie prawa karnego, przekształcona w zapisy ustawowe do dziś stanowi przedmiot dyskusji przedstawicieli nauki prawa karnego, znajdując zarówno zwolenników jak i oponentów 33 . Od czasu wydania kodeksu karnego z 1932 r. w polskim prawie karnym do dziś utrzymuje się stabilność rozwiązań prawnych, dotyczących zasad odpowiedzialności karnej. Należy przy tym dodać, że autor tego poglądu - Tadeusz Bojarski - stabilność ogólnych zasad odpowiedzialności karnej przewidzianą we wszystkich trzech polskich dwudziestowiecznych kodeksach karnych (z 1932, 1969 i 1997 r.) uznał ,za honorowanie dobrej tradycji polskiego prawa karnego" ${ }^{34}$. Tradycji, która swój początek wzięła z kodeksu karnego Juliusza Makarewicza. Na marginesie można by postawić pytanie, czy gdyby kodeks z 1932 r. nie był pierwszym, to też by odegrał taką

${ }^{31} \mathrm{~K}$. WIAK, Zasady gwarancyjne prawa karnego na tle rozwiazań komunistycznego prawa karnego Polski Ludowej, [w:] Komunistyczne prawo karne..., s. 73.

32 P. Kardas, op. cit., s. 514.

33 Tamże, s. 516; K. Siemaszko, Podżeganie i pomocnictwo do przestęsstw indywidualnych na gruncie kodeksu karnego z 1932 roku w świetle orzecznictwa Sadu najwyższego i pogladów doktryny, [w:] 'Culpa et poena'. Z dziejów prawa karnego. Materiały z konferencji poświęconej dziejom prawa karnego, Uniwersytet Jagielloński, Kraków 11-13 marca 2008 r., red. M. MikUŁA, Kraków 2009. s. 239-245.

34 T. BoJARSKI, op. cit., s. 12 i 15. 
samą rolę? Należy także wskazać, że obok rozwiązań nowych, każda nowo uchwalona ustawa karna posługuje się bardzo często konstrukcjami mającymi za sobą długą historię. Jak bowiem pokazała historia, po II wojnie światowej poddano w Polsce brutalnej krytyce wiele ustaw uchwalonych w okresie międzywojennym, zachowując w dalszym ciagu ich moc obowiązująca, co świadczy tylko o tym, że krytyka ta miała charakter ideologiczny a nie merytoryczny.

Kodeks karny z 1932 r. należy uznać nie tylko za wybitne dzieło jurydyczne, ale również naukowe. Na jego gruncie powstało obfite piśmiennictwo monograficzne i komentatorskie oraz poświęcone opracowaniu systemu prawa karnego. Będąc wytworem wybitnych osobowości i autorytetów, zawierając wiele nowatorskich rozwiązań teoretyczno prawnych był on namacalnym dowodem bardzo wysokiego poziomu polskiej nauki prawa karnego materialnego w tym okresie. I to właśnie być może w tym wysokim poziomie ówczesnej polskiej nauki prawa karnego, a tym samym także i kodeksu - którego nie osiagnęła on już nigdy potem - należy widzieć jego wpływ na rozwój nauki prawa karnego w Polsce. Zazwyczaj bowiem mamy do czynienia z relacją że im silniejsza nauka tym większy jej praktyczny wpływ na działalność legislacyjna, i na odwrót, im słabsza nauka tym mniejszy jej wpływ ${ }^{35}$.

Kodeks karny z 1932 r. - jak zauważył Andrzej Wąsek - poza swymi zaletami natury merytorycznej i formalnej posiadał jeszcze jeden niebagatelny dla nas emocjonalnie walor, że był kodeksem niepodległej Polski ${ }^{36}$. Dla niektórych karnistów, szczególnie tych pozostających w swoistej opozycji wobec zmian dokonujących się w polskim prawie karnym w latach 1944-1989, odwoływanie się do niego miało charakter symboliczny, „tak jak do orła w koronie”. Dzięki niemu jednak o polskim prawie karnym od prawie osiemdziesięciu lat można powiedzieć, że cechuje je humanizm i demokratyzm.

\footnotetext{
35 J. Tylman, op. cit., s. 127.

${ }^{36}$ A. WAূSEK, op. cit., s. 119. Niektórzy badacze piszą o nim nawet, że był „swojski”; J. SKUPIŃSKI, op. cit., s. 42.
} 
Kodeks karny z 1932 r. jak każda kodyfikacja prawa postawił przed nauką i praktyką różne problemy do rozwiązania, czasami bardzo trudne i sporne, a równocześnie doniosłe. Sam kodeks prezentując tak wysoki poziom wywindował również, zmusił polską naukę prawa karnego, by i ona również starała się osiągnąć taki sam poziom.

Również prowadzone dwukrotnie w Polsce po II wojnie światowej prace kodyfikacyjne pobudziły myśl naukową $\mathrm{w}$ dziedzinie prawa karnego oraz sięganie do kodeksu karnego z 1932 r., jako ciągle niedoścignionego wzorca. Zaś komentarz J. Makarewicza do tego kodeksu stanowi podstawowe źródło do badania i interpretacji ustawy karnej w ramach wykładni podmiotowo-historycznej, z uwagi na to, że zarówno w kodeksie z 1969 r., jak i z 1997 r. - wiele instytucji prawnych zachowało kształt niezmieniony w porównaniu z kodeksem z 1932 r. - stanowiącym do dziś istotne źródło dla badań nad obowiązującą ustawą karną ${ }^{37}$. Oczywiście w kodeksie karnym z 1969 r. instytucjom tym ,wkładając w stare szaty" nadano nową marksistowską treść, która od początku obowiązywania tego kodeksu ujawniła swoje ideologiczne oblicze. Kodeksowi temu bowiem przyszło akurat obowiązywać w okresie chwiania się ustroju politycznego w Polsce i cyklicznych kryzysów społecznych. Powrót do postępowych tradycji kodeksu karnego z 1932 r. nastapił dopiero w trakcie prac nad kodeksem z 1997 r. Na marginesie warto podkreślić, iż kodeks z 1932 r. pomimo, że był pierwszym polskim dwudziestowiecznym kodeksem wywołał najmniej głosów krytycznych i był rzadziej nowelizowany niż dwa pozostałe.

Od czasu jego uchwalenia pojawiał się on zawsze, gdzieś tam w tle przy każdej próbie reformy, zmiany modelu prawa karnego obowiązującego w Polsce. A odwoływanie się do niego uznano za przejaw sięgania do najbardziej postępowych tradycji i osiągnięć w polskiej nauce i w polskim prawie karnym. Rozpatrując znaczenie kodeksu karnego z 1932 r. należy także wskazać na dwie zasady leżące u podstaw zmian w prawie karnym: pierwszą - stałości prawa, i drugą - ko-

37 K. Pol, Juliusz Makarewicz, [w:] Poczet prawników polskich, Warszawa 2000, s. 870 . 
nieczności zmian prawa w celu dostosowania go do zmieniających się warunków życia ${ }^{38}$.

Jan Skupiński, pisząc o tradycji i współczesności w polskim prawie karnym, konkludował iż „historia polskiego prawa karnego, oglądana z perspektywy już ponad osiemdziesięciu lat, dowodzi, że gdy tworzenie prawa karnego wolne jest od wpływów politycznych, a odbywa się bez pośpiechu i w kompetentnym [podkreślam kompetentnym - J.K.] gronie, wpływa to zdecydowanie korzystnie na jego jakość i racjonalność. Inne postępowanie przynosi zaś efekty, niestety, odwrotne" ${ }^{39}$. Do wypowiedzi tej - wzmacniając ją - można jeszcze dodać słowa Elżbiety Darmorost-Sierocińskiej, która pisząc o znaczeniu kodeksu karnego z 1932 r. na ukształtowanie się polskiej myśli prawniczej, zauważyła iż jest on dziełem „odpowiedzialnej działalności kodyfikacyjnej w łonie Komisji Kodyfikacyjnej" ${ }^{40}$. W kontekście tego znana jest powszechnie wypowiedź Józefa Piłsudskiego na spotkaniu z członkami Komisji Kodyfikacyjnej w 1921 r., iż „wadą Komisji Kodyfikacyjnej jest, że jej członkowie, przeważnie profesorowie, dążą do doskonałości" i przez to opóźniają przygotowanie jednolitych kodeksów". Na co przewodniczący Komisji, Franciszek Ksawery Fierich, miał odwagę odpowiedzieć: „Nie można się spodziewać prędko owoców pracy, jeśli te mają być dojrzałe" ${ }^{41}$. Całe szczęście, że w przypadku kodeksu karnego z 1932 r. członkowie Komisji nie ulegli

38 T. Szymanowski, Znaczenie nowelizacji prawa karnego z punktu widzenia polityki karnej z uwzględnieniem ostatnich zmian, [w:] Węzlowe problemy prawa karnego, kryminologii $i$ polityki kryminalnej. Ksiega pamiatkowa ofiarowana Profesorowi Andrzejowi Markowi, red.: V. Konarska-Wrzosek, J. LachowsKi, J. WóJCikieWicz, Warszawa 2010, s. 925.

39 J. SKUPIŃSKI, op. cit., s. 48.

${ }^{40}$ E. Darmorost-SierocińsKa, Kodyfikacja prawa karnego..., s. 369.

${ }^{41}$ S. Grodziski, Wosiemdziesięciolecie Komisji Kodyfikacyjnej (Geneza i struktura), «PiP» 55.4/2000, s. 18, przyp. 24; J. KoredczuK, Spory o ksztalt prawa karnego w Polsce międzywojennej, [w:] Na szlakach Niepodległej. Polska myśl polityczna i prawna w latach 1918-1939, red.: M. MARSZAŁ, M. SADOwSKI, Wrocław 2009, s. 259. 
presji słów Marszałka. Dzięki temu kodeks ten nawet dziś - na tle kodeksu z 1997 r. - jest bardzo pozytywnie oceniany ${ }^{42}$.

Kończąc należy wyrazić podziękowanie Katedrze Prawa Karnego Katolickiego Uniwersytetu Lubelskiego, kierowanej przez Panią Profesor Alicję Grześkowiak i założonemu w 2006 r. z inicjatywy jej pracowników Stowarzyszeniu Naukowemu Prawa Karnego im. Profesora Juliusza Makarewicza, za doprowadzenie do przetłumaczenia na język polski „Wstępu do filozofii prawa karnego w oparciu o podstawy historyczno-rozwojowe" Juliusza Makarewicza (Lublin 2009) i wydania pierwszego tomu jego „Prac rozproszonych. Publikowanych w latach 1895-1901" (Lublin 2010). Na nowo odkrywając jakby J. Makarewicza umożliwiają one poznanie jego wcześniejszych poglądów naukowych, które później przekuł on w normy kodeksu karnego z 1932 r. Dając tym samym lepszą możliwość oceny tego kodeksu na rozwój polskiej nauki i prawa karnego w XX w.

\section{The Significance of the Polish Penal Code of 1932 for the Criminal LaW and Academic Education Development in Poland in the $20^{\text {Th }}$ Century}

\section{Summary}

Since the year of 1932 marking the publication date of The Polish Penal Code also known as "Makarewicz Code", there were strong indications that it would have a profound impact on the advancement in the field of Polish penal law and the academic-scientific area. Drawing from the highest standards and greatest solutions in Europe (i.e. The Code of Switzerland), The Polish Penal Code immediately gained substantial recognition abroad. Following World War II, it became an integral part of the socialist penal law system governing Poland at that time in history.

${ }^{42}$ Pomijam w tym momencie nieliczne wypowiedzi całkowicie negatywnie oceniające kodeks karny z 1997 r.; por. np. W. MĄcıor, Złe prawo należy zmienić, [w:] Aktualne problemy prawa karnego. Księga pamiatkowa z okazji Jubileuszu 70. Urodzin Profesora Andrzeja J. Szwarca, red. Ł. PoHL, Poznań 2009, s. 367-379. 
Despite the numerous attacks it was exposed to, The Code served as an academic tool for educating many generations of lawyers and until 1969 it remained a main source book for law studies lectures. Additionally, it was considered to be a synonym of well-founded and stable Polish law and was applied as a benchmark for codification works in Poland dating back to 1969 and 1997 . Having regard to the declarations presented by classical and sociological school with its reference to the penal law education, The Penal Code of 1932 had a great influence on the evolution of Polish academic education and criminal law in Poland of 20th century. Today this statement is reinforced by the fact that its author - Juliusz Makarewicz is regarded as the most prominent penal law professor. The Makarewicz Code is not only recognized as an outstanding judiciary achievement but also as a valuable academic-scientific point of reference. It is a symbol of the finest traditions in Polish law associated with progress, innovation and the one that elaborates on institutions that secure and attest to obeying the penal law regardless of the political roles it may play. 